\title{
The management of hyperglycaemia in patients on enteral nutrition in Beaumont Hospital
}

\author{
R Tully ${ }^{*}$, H Giuden, E Fanning \\ From International Conference for Healthcare and Medical Students 2011 \\ Dublin, Ireland. 4-5 November 2011
}

\section{Objectives}

To audit current practices in the management of hyperglycaemia in in-patients receiving enteral nutrition in Beaumont Hospital. The aims include:

- To examine the use of specific enteral feeds and their effects on hyperglycaemia

- To examine the medical management of hyperglycaemia

\section{Methods}

Setting: A quantitative retrospective audit was carried out over 4 months. The medical charts and dietetic record cards of patients with raised blood glucose levels (defined as $\geq 8 \mathrm{mmol} / \mathrm{L}$ ) who were receiving enteral nutrition in Beaumont Hospital were collected by the department of Nutrition and Dietetics during the months of May to August.

Patients: Medical charts and dietetic record cards of patients with raised blood glucose (BGLs) levels whilst receiving enteral nutrition during the months of May to August 2011 were included in this audit. Twenty-four patient's charts were eligible for the audit.

Main-outcomes/ measures: Use of diabetes specific feeds versus standard feeds, mean BGL $(\mathrm{mmol} / \mathrm{L})$ on each feed.

\section{Results}

Of the 24 patients, $21 \%$ percent $(n=5)$ of patients were started on a diabetes specific feed as a first line. $25 \%(n=6)$ of patients were changed to a diabetes specific feed during the audit. $66 \%$ percent $(n=16)$ of patients were on insulin. $42 \%(n=10)$ of patients had endocrine team involvement. It was found that $46 \%(n=11)$ of patients were on a diabetic specific feed during their admission. Furthermore there was only a slight reduction in average high BGLs for

Royal College of Surgeons in Ireland, Ireland these patients when compared to patients not on diabetic specific feeds.

\section{Conclusions}

The aims of this audit were met by examining the use of specific enteral feeds and their effects on hyperglycaemia.

Published: 9 July 2012

\section{doi:10.1186/1753-6561-6-S4-P41}

Cite this article as: Tully et al:: The management of hyperglycaemia in patients on enteral nutrition in Beaumont Hospital. BMC Proceedings 2012 6(Suppl 4):P41.
Submit your next manuscript to BioMed Central and take full advantage of:

- Convenient online submission

- Thorough peer review

- No space constraints or color figure charges

- Immediate publication on acceptance

- Inclusion in PubMed, CAS, Scopus and Google Scholar

- Research which is freely available for redistribution

\section{() Biomed Central}

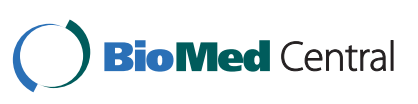

C 2012 Tully et al; licensee BioMed Central Ltd. This is an Open Access article distributed under the terms of the Creative Commons Attribution License (http://creativecommons.org/licenses/by/2.0), which permits unrestricted use, distribution, and reproduction in any medium, provided the original work is properly cited. 